\title{
1924年丹沢地震（Mj7.3）の震源断層モデルの推定と首都圈の強震動評価 ESTIMATION OF THE FAULT FOR THE 1924 TANZAWA EARTHQUAKE (Mj7.3) AND EVALUATION OF STRONG GROUND MOTIONS IN THE TOKYO METROPOLITAN AREA
}

\author{
早川 崇*, 片岡俊一 ${ }^{* *}$, 宮腰淳 一 ${ }^{* * *}$, 佐藤俊 明***, 横田治彦*** \\ Takashi HAYAKAWA, Shunichi KATAOKA, Junichi MIYAKOSHI, \\ Toshiaki SATO and Haruhiko YOKOTA
}

\begin{abstract}
We estimated the fault of the 1924 Tanzawa earthquake (Mj7.3), which was the largest aftershock of the 1923 Kanto earthquake (Ms8.2). We could successfully reproduce the observed waveforms in central of Tokyo based on the estimated fault model. This is very important to investigate the characteristics of ground motions by M7 events occurring in the Tokyo Metropolitan area because we only have a few observed waveforms of such events in central Tokyo. Finally, we calculated ground motions around Tokyo metropolitan area by the estimated fault model. The simulated ground motions do not exceed the design spectra around the area but in west of Kanagawa Pref.
\end{abstract}

\footnotetext{
Keywords : strong ground motions, fault model, semi-empirical method, three-dimensional finite difference method, the 1924 Tanzawa Earthquake, the Tokyo Metropolitan area

強震動, 断層モデル, 半経験的波形合成法, 三次元有限差分法, 1924 年丹沢地震, 首都圈
}

\section{1.はじめに}

南関東でM 7 程度の地震が今後 30 年で発生する確率は高く, 地 震調查研究推進本部によって $70 \%$ 程度と発表されている ${ }^{1}$. $M 7$ 規 模の地震は構造物に甚大な被害を与える場合があり，首都圈で発生 する M7 規模の地震による強震動評価は非常に重要な課題である. また、プレート境界で今後発生する M8 規模の関東地震に対する耐 震安全性の検討の観点からは, 本震の地震動推定と共に、その直後 に発生した多くの M7 規模の余震の地震動を推定することが重要で ある.

強震動予測においては地下構造及び震源断層の地域性の評価が結 果に大きく影響する. 関東平野では物理探查結果や豊富な中小地震 の観測記録を用いて作成された三次元地下構造モデル 2)，3，4) が提 案され, 周期数秒以上の長周期において地下構造の増幅特性が面的 に評価可能である. また短周期においてもスペクトルインバージョ ンから推定された増幅率 5) やAVS30 から推定された増幅率 6) 等か ら地下構造の増幅特性を面的に評価することが可能である。一方， 震源断層に関しては未解明な部分が多く残されている。この主な原 因は M7 規模の地震が首都圈で近年発生しておらず, 震源断層の特 性を推定するために必要な断層近傍の記録が殆ど得られていないこ とに一因がある.
南関東で発生したM 7 規模の地震として 1923 年の大正関東地震 の余震群がある.これら余震群は東京本郷において複数の地震計で 不完全ながら観測されている.この観測記録を基に震源断層を推定 できれば, 今後首都圈周辺で発生する M7 規模の地震による首都圈 の強震動を考える上で有用な資料となる，前述したように首都圈の 地下構造は三次元的に明らかになってきており, 東京本郷の記録が 説明できる震源断層は推定可能と考えられる.

本研究では 1924 年 1 月 15 日の丹沢地震 (M7.3) (以後, 丹沢地 震) を取り上げた. この地震の巨視的震源パラメータは佐藤・片岡 7)により調べられているが, 詳細な震源断層モデルは提案されてい ない. 丹沢地震は規模が大きく首都圈に近いため断層の不均質性が 地震動に大きく影響する. 本研究ではアスペリティと背景領域から なる震源断層を推定し, 三次元差分法及び経験的グリーン関数法に より首都圈の広帯域な強震動を推定した.

\section{2. 観測記録}

丹沢地震は東京本郷 (HNG と記す) で Ewing 式地震計, 教室強 震計 ${ }^{8)}$ の地震計で記録されている。

Ewing 式の記録については, オリジナル記録のトレースは文献 9) に, そこから推定した地動については文献 ${ }^{10}$ に記載があり, 120 秒

\footnotetext{
* 清水建設(株)技術研究所

** 弘前大学大学院理工学研究科 博士 (工学)

*** 清水建設(株技術研究所 博士(工学)
}

SHIMIZU Corp., Institute of Technology

Hirosaki University, Dr. Eng.

SHIMIZU Corp., Institute of Technology, Dr. Eng. 
間の記録が数值化されている。これらの文献では記録が SE-NW， SW-NE方向で示されているが, 本論ではN-S, E-W 方向に変換した. $2 \mathrm{~Hz}$ でハイカットした加速度波形を図 1 に示寸.この地震計は他の 2 機種とは違い, イベントトリガー方式であり, 地震動を感知して から記録を開始する. そのため, 初動は得られていない. 全体的に 振幅の減衰は緩やかであり, HNG が破壊伝播方向に位置していない ことが推察される. 図 1 の加速度波形を数值積分して求めた $2 \mathrm{~Hz}$ 以下の変位波形を図 2 に示寸. 時刻 $70 \sim 90$ 秒付近に周期 10 秒程度 の大きな波群が存在する.この波群が主要動から遅れて到達するこ と, 分散が見られること, 周期が 10 秒程度であることから関東平野 の堆積層による Love 波群と考えられる.

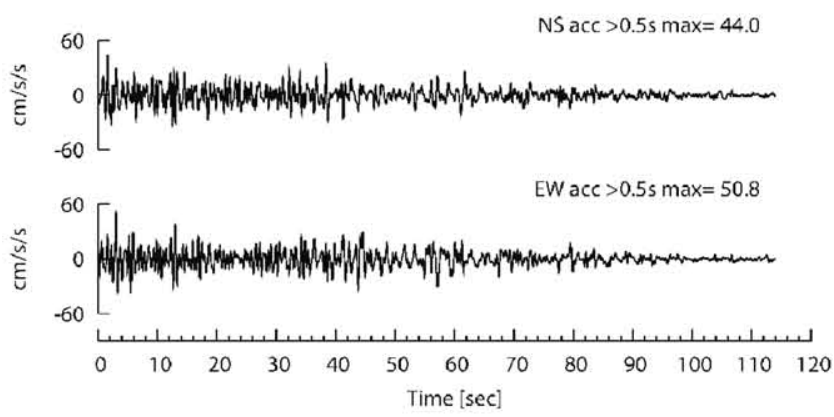

図 1 Ewing 式地震計で記録された本郷の観測記録（加速度）
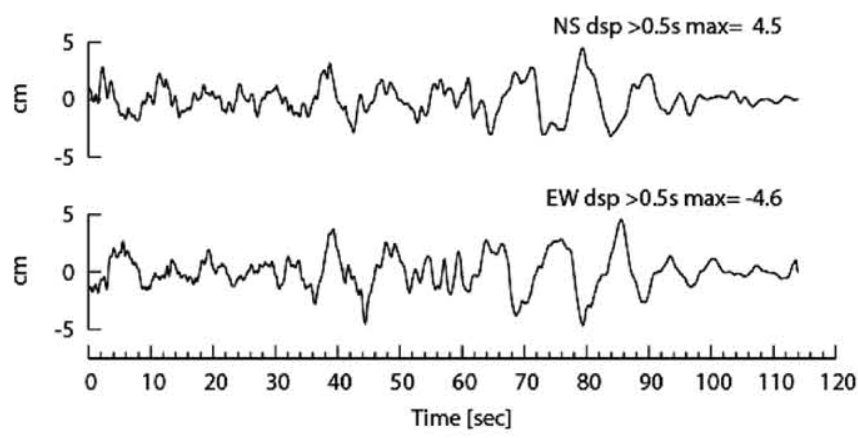

図 2 Ewing 式地震計で記録された本郷の観測記録（変位）

教室強震計による丹沢地震の記録を画像処理により白黒反転させ て図 3 に示寸．振り切れることなく長い時間記録している，記録を 見ると, 初動後極めて長周期の位相（図中のA）が見られるが, 対 応すると思われるタイムマーク (図中の矢印付き線 $\mathrm{a}$ と $\mathrm{b}, 1$ 分間 を表す）はその前後のタイムマークの間隔に比べて, 1.3 倍程度長 くなっているので, 紙送りが正常でなかったために生じたものと考 えている.この記録でも, NS 成分では初動から 80 秒程度, EW 成 分では 60 秒程度経った時点で振幅が大きくなっており, 後続位相が 大きくなることは Ewing 式地震計の記録と対応している.

以上のように，2つの地震計による丹沢地震の記録は相互に矛盾 がない.そこで, 以下の検討には全容をきれいに記録している Ewing 式地震計の記録を用いた。

\section{3. 地下構造モデルの検証}

文献 4 による三次元地下構造モデルを用い, 三次元差分法 ${ }^{11)}$ によ り周期 3 秒以上の地震動計算を行って, 丹沢地震の断層モデルの推 定・検証及び首都圈の長周期の地震動評価を行った. 地下構造モデ
ルで最も重要なことは, 対象地震による評価地点の地震動の再現能 力である. 文献 4 では, 丹沢地震の震源域の西南に位置する 1990 年の小田原の地震（Mj5.1）（図 4）で関東平野の観測記録の再現性 を確認している.このことが文献 4)による地下構造モデルを用いた 理由である. 新しいモデル22,3) では, 新しい物理探査データ等が反 映されているが, 小田原地震ほど丹沢地震に近い地震で再現性を確 認していない

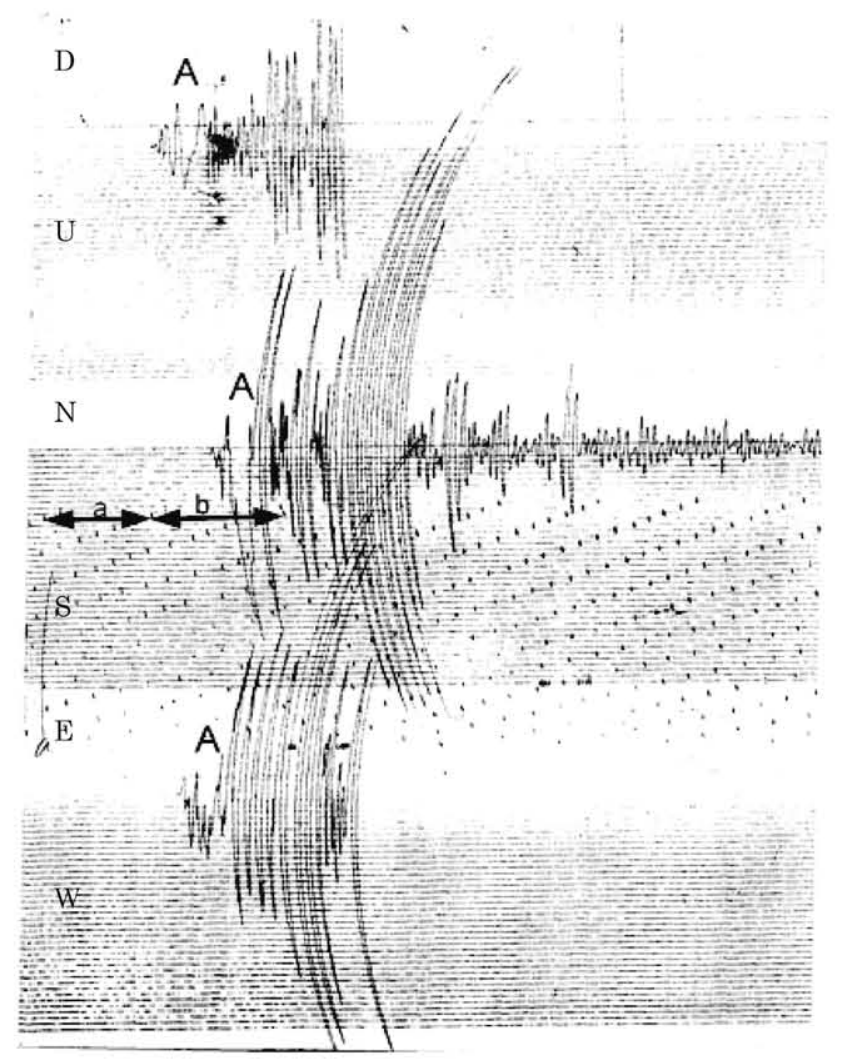

図 3 教室強震計で記録された本郷の観測記録

地下構造モデルは丹沢地震の震源域の南側の地震に対して再現 能力が確認されているが, 北側の地震では再現能力が確認されてい ない. そこで断層モデルの北側で発生した 1983 年 8 月 8 日の神奈川 県西部の地震 (Mj6.0, 梁さ $22 \mathrm{~km}$ ) の越中島（ETC）における観測記 録を三次元差分法でシミュレートレて, 地震動の再現能力を確認し た. ETC は HNG に近く, SN 比が良好な速度記録が得られている. 対象とした周期は 3 秒以上とした. 図 4 に 1983 年の神奈川県西部の 地震の震央, HNG, ETC の位置を示す.

この地震は規模が比較的小さく ETC から遠いため点震源でモデ ル化した. 震源位置, 深さと発震機構は気象庁による推定值 ${ }^{12)}$ を用 いた. 震源時間関数は二等辺三角形でモデル化し, 継続時間は図 4 に示す SZJ の記録で最初に到達した S 波のパルス幅から読み取った. また地震モーメントはSZJ の EW 成分の速度振幅と計算波が一致す るように本論で推定した. その結果, 継続時間 1.5 秒, 地震モーメ ント $21 \times 10^{17} \mathrm{Nm}$ と推定した.

図 5 は 1983 年神奈川県西部の地震の SZJ と ETC における計算波 と観測波の比較である. ETC の計算波は観測波の振幅レベルおよび 経時特性を再現している. とくにNS成分の $60 \sim 90$ 秒付近に認めら れる長周期の大きな振幅の後続動が再現されている. 今回用いた三 
次元地下構造モデルは震源域北側の地震においても地震動の再現能 力を有し, 断層モデルの検証や首都圈の地震動評価に有用であると 考えられる.

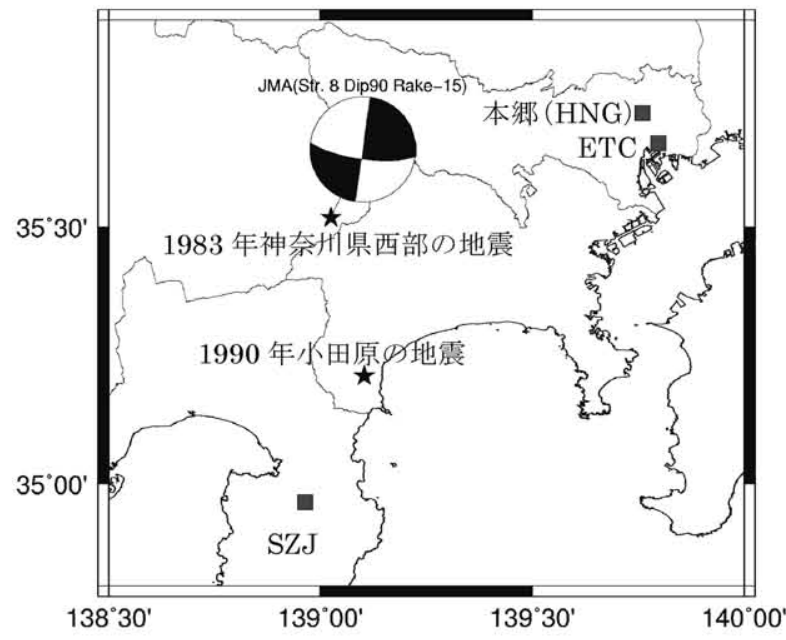

図 41983 年神奈川県西部, 1990 年小田原の地震の震源 およびHNG，ETC，SZJ

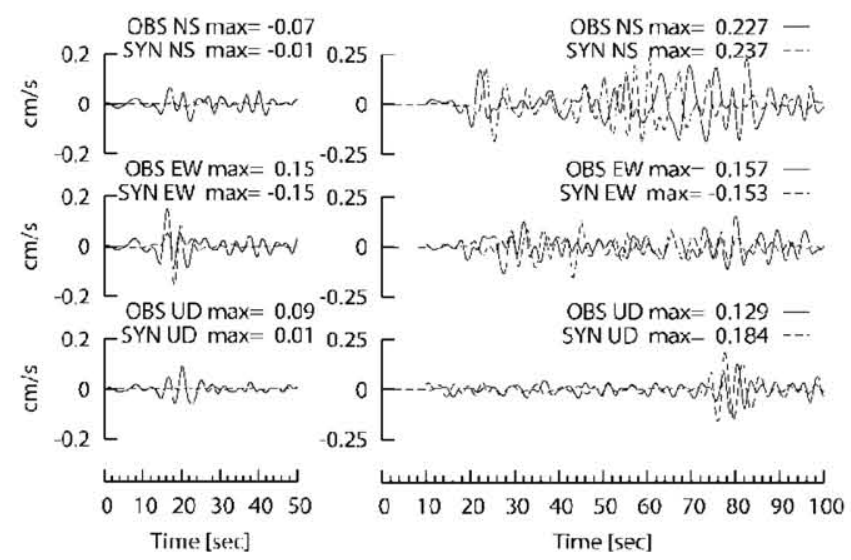
SZJ

ETC

図 51983 年神奈川県西部の地震の

SZJ とETCにおけるシミュレーション

\section{4. 震源断層の推定}

震源断層には 2 つのグメントを想定した．本論ではまず各々の セグメントのアスペリティの設定を説明した後, 残る断層パラメー 夕の設定を説明する. 本研究では情報が不足して拘束が効かない断 層パラメータは, まず地震調查研究推進本部による手順 ${ }^{13)}$ (以後, レシピと呼ぶ）に従って平均的な断層パラメータを設定することを 基本方針とした.

\section{(1) アスペリティ1の推定}

丹沢地震の震源断層に関する既往の調査には, 1 ) 佐藤・片岡に よる解 ${ }^{7)}, 2$ ) 気象庁による震央位置 ${ }^{14)}$ がある. 佐藤・片岡は岐皁 の記録に見られるモホ反射 $\mathrm{S}$ 波と Depth phase の時間差が一次元構 造における理論值と一致するように震源位置を推定し, 岐阜と仙台 の記録を用いた waveform modeling でメカニズムを推定した. 佐藤・
片岡の解の震源位置は断層面の中で最も地震動を放出した部分に相 当する. 地震モーメント, メカニズム, 震央に関してはこれらの推 定値をそのまま用いた. 丹沢地震の断層面には佐藤・片岡の解によ る二つの節面のうち本震の断層面と近い傾斜の節面を採用した.

最初に強震動に強く影響するアスペリティ位置の推定を行った. 図 6 に佐藤・片岡による解 $(\boldsymbol{\Delta})$, 気象庁による震央 $(\star)$, 本震の 最終すべり量分布 (実線) ${ }^{15}$ ) と本震から丹沢地震発生までの余震の 分布 ${ }^{14)}$ () を示す. 最終すべり量分布は本震後の測地データと本 震の実体波の同時インバージョンで推定されたすべり量である.ア スペリティの位置は，1）佐藤・片岡の解の近傍. 2) 本震から丹沢 地震発生までの間で余震の発生が少ない領域, 3) 本震のす心゙り量が 大きい領域の縁，の三つの条件から推定した．2）の理由は丹沢地 震のアスペリティでは本震後でも固着しており, 余震の発生回数は 少ないと考えたことによる. 3）の理由は本震のアスペリティの縁 で最大余震が発生している事例 ${ }^{16)}$ を考虑したことによる.レシピに よると地震モーメントからアスペリティ面積は $339 \mathrm{~km}^{2}$ と推定され る. 同程度の面積で前述した 3 つ条件に適合する場所として, 図 6 に太点線で示寸領域 A, 領域 B, 領域 C が挙げられる. 宇津 ${ }^{17)}$ に よると三島と甲府の震度が同じであり, アスペリティを領域 C に仮 定することは難しい，領域 A ではモーメントの重心が佐藤・片岡の 解よりも北東に外れてしまう。 そこで本論では領域 B に地震規模か ら経験的 ${ }^{18)}$ に 2 個のアスペリティを余震の空白域を偏りなく自然に 埋めるように想定した。 (以後, アスペリティ 1). 位置と面積は空 白域の中で任意性が残るが, 情報がないためこれ以上の検討は行わ なかった。

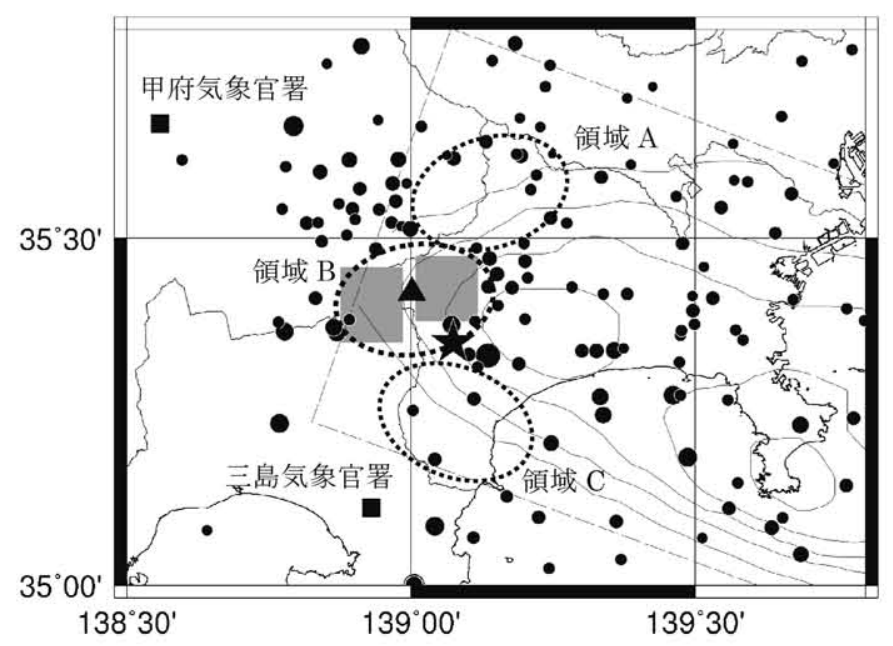

図 6 佐藤・片岡の解 $(\boldsymbol{\Delta})$, 本震のすべり量分布 (実線),

本震から丹沢地震までの間に発生した余震（）の分布と アスペリティ 1 (灰色部分)

その結果, アスペリティ 1 の合計面積は $286 \mathrm{~km}^{2}$ となり, レシピ による面積 $339 \mathrm{~km}^{2}$ とほぼ等しい. アスペリティ 1 は丹沢地震の主要 なアスペリティと考えられる. アスペリティ 1 の梁さは佐藤・片岡 の解の梁さとほぼ一致するように設定し, アスペリティ 1 の三次元 形状を設定した.

（2）アスペリティ2の推定

図 2 の 30〜55 秒と, 60〜90 秒に見られる大振幅の後続動の水平 
面の粒子軌跡を図 7 に示す. 2 章でも述べたが 60 〜 秒の波群は堆 積層による Love 波と考えられる. 30〜 55 秒は周期が 6 秒程度で, Love 波と主軸がほぼ直交していることから Rayleigh 波の可能性が 高い.
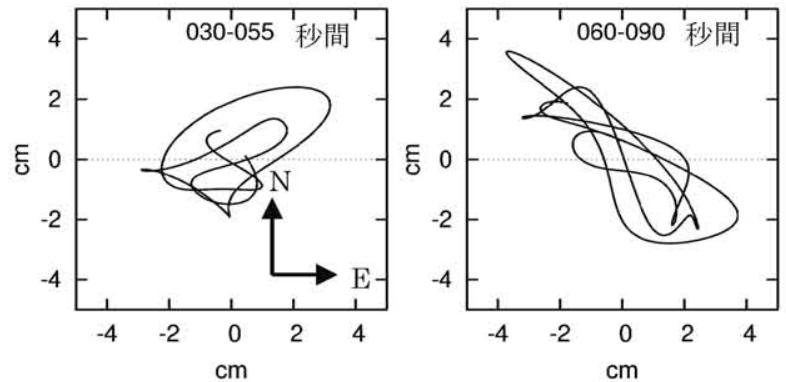

図 7 HNG の観測記録（周期 3 秒以上）の後続動の粒子軌跡

60〜 90 秒の粒子軌跡の主軸は北西一南東である. アスペリティ 1 は本郷から見て西南西に位置しており, シミュレーションでは南西 方向からの Love 波を十分に再現できない.そこで本郷から見て南西 に位置する相模湾で，本震のアスペリティの縁に位置する領域 D に 小さなアスペリティを仮定した（アスペリティ2）. 図 8 に領域 D を 示す. 地震基盤は三浦半島から横浜に向かって比較的急に深くなる ため, 相模湾の浅い地震では堆積層表面波が効率よく生成される. 記録が少ない領域 Dの地震に対して地下構造モデルの妥当性が検証 されていない。しかし文献 4 に示される小田原の地震のスナップシ ヨットにおいて, ENS,OFN,YKH では相模湾から三浦半島をへて関 東平野に達する波群が含まれている様子がみてとれる。このような 地震波の伝播は, 領域 D の地震波と同様であり, 文献 4 で示される ENS,OFN,YKH の記録の再現は領域 D の地震に対する地下構造モデ ルの直接的な検証にはならないが, 傍証になると考えられる.

アスペリティ 2 の面積は基本方針に従ってレシピによるアスペリ ティとアスペリティ 1 の面積の差から求め, レシピに従ってアスペ リティ 2 の地震モーメントを求めた。 その結果, アスペリティ 2 は 断層全体の $16 \%$ と小さい地震モーメントであった.

HNG で観測された大振幅の Love 波を再現するためには，領域 D の中でもさらにLove波が効率良く生成される位置にアスペリティ 2 を設置する必要があった. 図 8 に示す領域 D に S1, S2, S3 の点震源 を仮定し, 三次元差分法で HNG の地震動を計算して Love 波群の生 成効率が高い位置を探した．アスペリティ 2 の断層面はアスペリテ ^1の断層面と同一平面上に設定する. そのため点震源の深さは S1, $\mathrm{S} 2, \mathrm{~S} 3$ における同平面上の深さ $(\mathrm{S} 1$ は $11.0 \mathrm{~km} 、 \mathrm{~S} 2$ と 33 は $4.6 \mathrm{~km}$ ) とした，点震源のメカニズムは佐藤・片岡の解, 地震モーメントは アスペリティ 2 の地震モーメントとした. 震源時間関数は二等辺三 角形とし，継続時間はアスペリティ 2 の等価半径を破壊伝播速度で 除して 2.4 秒と見積もった. 図 9 に HNG における計算波の N135E 成分を点震源 S1, S2, S3 で比較して示す. N135E は記録の後続動の 主軸方向である. 点震源が S3 の場合最も強く Love 波が励起され, 経時特性も観測波と似ている。そこでアスペリティ 2 の位置を S3 と想定して検討を進めた。

\section{(3) 断層モデル}

前節まででアスペリティ 1 の形状・位置とアスペリティ 2 の位置
が決定した. アスペリティ 2 と背景領域の面積及び微視的な断層パ ラメータはレシピで算出できる. 設定が必要な, 残る断層パラメー 夕は破壊様式, 背景領域の形状・位置とアスペリティ 2 の形状であ る.これらは拘束できる資料がないため本論で想定した.

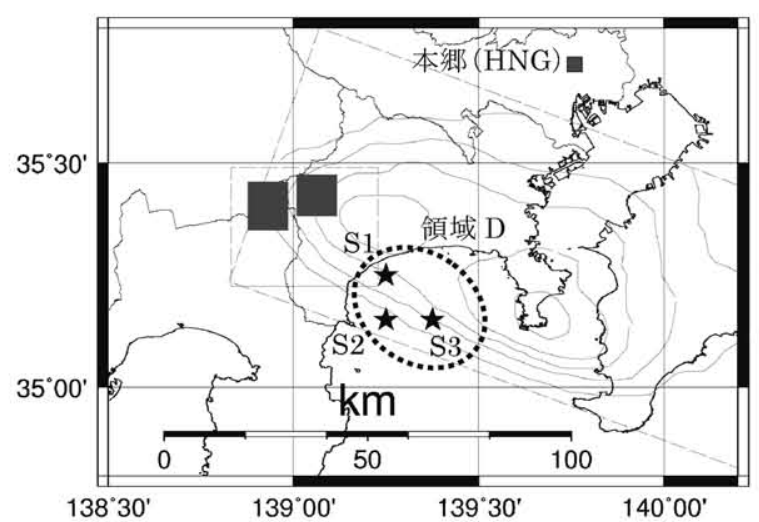

図 8 HNG，領域 D とアスペリティ 2 の位置検討用の点震源
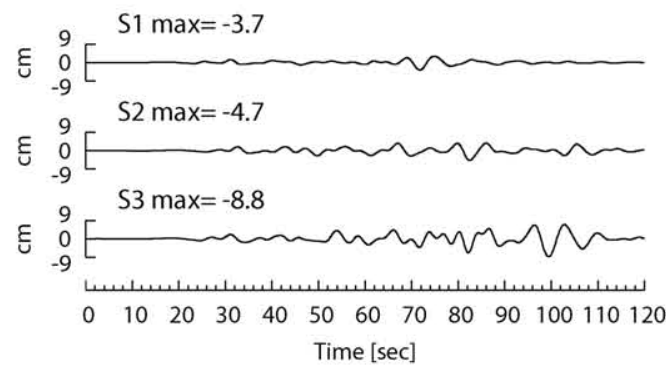

図 9 点震源による HNG における計算波（N135E 成分）

表 1 巨視的断層パラメータ

\begin{tabular}{|c|c|c|c|}
\hline & & & 備考 \\
\hline 断層原点 & 北緯 & $35.23^{\circ}$ & 南東端 \\
\hline \multirow[t]{3}{*}{ (西のセグメント) } & 東経 & $139.23^{\circ}$ & \\
\hline & 媣さ & $9 \mathrm{~km}$ & \\
\hline & 面積 & $1250 \mathrm{~km}^{2}$ & \\
\hline 断層原点2 & 北緯 & $139.4^{\circ}$ & 南東端 \\
\hline \multirow[t]{3}{*}{ (南東のセグメント) } & 東経 & $35.11^{\circ}$ & \\
\hline & 媣さ & $2.00 \mathrm{~km}$ & \\
\hline & 面積 & $229 \mathrm{~km}^{2}$ & \\
\hline \multicolumn{2}{|l|}{ 走向, 傾斜, すべり角 } & $, 30^{\circ}, 120^{\circ}$ & 文献7 \\
\hline 破壊開始点 & 北緯 & $35.350^{\circ}$ & 文献14 \\
\hline \multirow[t]{2}{*}{ (西のセグメント) } & 東経 & $139.074^{\circ}$ & 同上 \\
\hline & 媣さ & $17 \mathrm{~km}$ & 同上 \\
\hline 破壞開始点2 & 北緯 & $35.170^{\circ}$ & \\
\hline \multirow[t]{2}{*}{ （南東のセグメント） } & 東経 & $139.230^{\circ}$ & \\
\hline & 樑さ & $5 \mathrm{~km}$ & \\
\hline 破壊様式 & & 同心円状 & \\
\hline 地震モーメント & & $5.40 \mathrm{E}+19 \mathrm{Nm}$ & 文献7 \\
\hline モーメントマグニチュ & $2-F \mathrm{Mw}$ & 2.4 & $\log M_{0}=1.5 M_{W}+16.1$ \\
\hline 断層面積 & & $1479 \mathrm{~km}^{2}$ & 文献13の (2)式 \\
\hline 破壊伝播速度 & & 3.0 & 文献15 \\
\hline
\end{tabular}


背景領域はアスペリティ 1 とアスペリティ 2 の周囲にそれぞれ付 与し，2つの背景領域がつながるように配置した（図 10)。レシピ にしたがって断層パラメータを設定し，アスペリティ 2 の形状をほ ぼ正方形にして震源から同心円状で破壊させると HNG の後続動が 記録を下回った．そこで破壊伝播効果で記録の再現性が向上するよ うに, アスペリティ1からの破壊の連続性を考慮して, アスペリテ イ 2 の破壊開始点を図 10 の位置に想定した。

しかしながら HNG の後続動が依然として記録を下回った. そこ でレシピの枠組みを越えて，記録の再現性が向上するようにアスペ リティ 2 のすバり量と応力降下量を可能な範囲内で検索した，その 結果, すべり量と応力降下量をレシピの 2 倍とし, 地震モーメント を保つようにアスペリティ 2 の面積は当初の半分とした.

2 つの破壊開始点の時間差は, 破壊開始点間の距離を破壊伝播速 度で除して求めた後, 計算波と観測波の位相が一致するように設定 した．最終的に時間差を 13 秒に設定した（初期值は 9.4 秒）.

断層パラメータを表 1 と表 2 に示す. 図 10 に断層モデルを示す.

表 2 微視的断層パラメータ

\begin{tabular}{|c|c|c|}
\hline & & 備考 \\
\hline \multicolumn{3}{|l|}{ アスペリティ1 } \\
\hline 面積 $\left(\mathrm{km}^{2}\right)$ & 154 (西), 132 (東) & \\
\hline すべり量(m) & 1.69 (西), 1.83 (東) & 文献13 (9),(15),(19)式 \\
\hline 応力降下量(Mpa) & 10.1 & 文献13 (11),(12),(13),(14)式 \\
\hline \multicolumn{3}{|l|}{ アスペリティ2 } \\
\hline 面積 $\left(\mathrm{km}^{2}\right)$ & 27 & $\begin{array}{c}\text { (総面積[文献13(12)式]ーアスペリ } \\
\text { ティ1面積) } / 2\end{array}$ \\
\hline すべり量(m) & 1.07 & 文献13 (9),(15),(19)式の2倍 \\
\hline 応力降下量(Mpa) & 20.2 & アスペリティ1の2倍 \\
\hline \multicolumn{3}{|l|}{ 背景領域 } \\
\hline 面積 & 1166 & 断層面積ーアスペリティ面積 \\
\hline すべり量 & 0.31 & 文献13 (17),(18)式 \\
\hline 応力降下量(Mpa) & 1.9 & 文献13 (23)式 \\
\hline
\end{tabular}

*剛性率は密度 $2.9 \mathrm{~g} / \mathrm{cm}^{3}, \mathrm{~S}$ 波速度 $3.9 \mathrm{~km} / \mathrm{s}^{4)}$ から算定

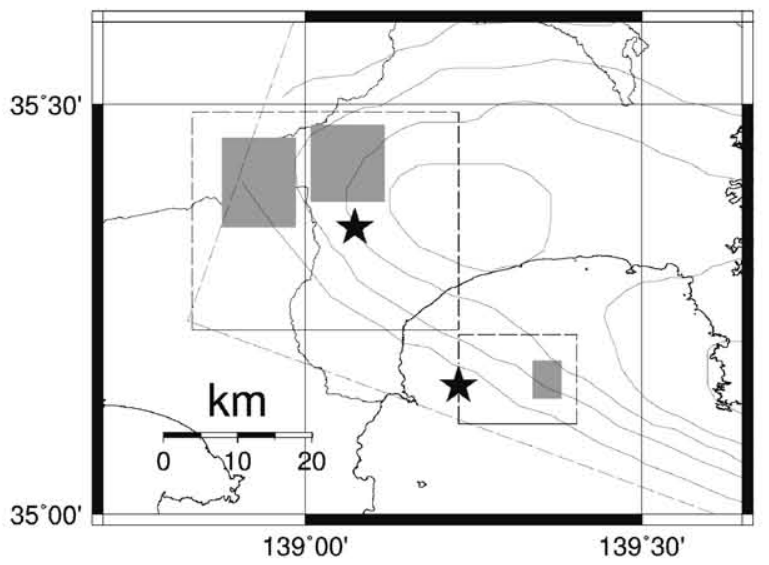

図 10 断層モデル（ネは破壊開始点，黒部分はアスペリティ）

\section{5. 断層モデルの検証}

破壊メカニズムとすべり量が強く影響する周期 3 秒以上の長周期 の地震動と, 応力降下量が比較的強く影響する震度の両面から, 断 層モデルの地震動の再現性を確認した.

\section{（1）長周期の地震動の再現性による検証}

三次元差分法で HNG の記録をシミュレートして，その再現性を 確認した.レシピを参考にすべり時間関数には中村・宮武 ${ }^{199}$ を用い, fmax は $6 \mathrm{~Hz}$ とした. すべり時間関数の設定に用いた断層幅は, アス ペリティの場合は各アスペリティ面積の平方根, 背景領域は各セグ メントの面積の平方根とした. 図 11 に差分法の発震時刻を 0 秒とし てプロットした HNG におけるアスペリティ 1 とその背景領域の計 算波を, Ewing 式地震計の観測波と比較して示寸. 記録開始の正確 な時刻は不明である．観測波の第一波は計算波の $\mathrm{S}$ 波の第一波と考 えて計算波と観測波を重祖いた。4(2)節で述べたように後続動が 再現されていない. 図 12 には断層全体による計算波を示す. 断層全 体の再現波は振幅, 位相ともよく観測波を再現している. 図 13 は図 12 の再現波の $90 \sim 120$ 秒の粒子軌跡を観測と比較して示している. 観測波の後続動の主軸（北西－南東方向）を再現している. HNG の長周期地震動をよく再現できる断層モデルであることが確認でき る.

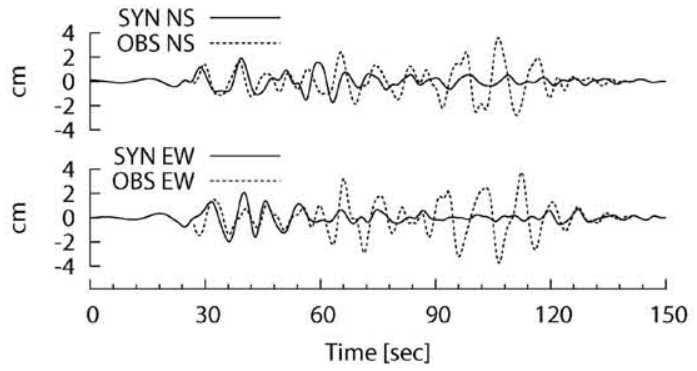

図 11 アスペリティ 1 とその背景領域による観測波の再現

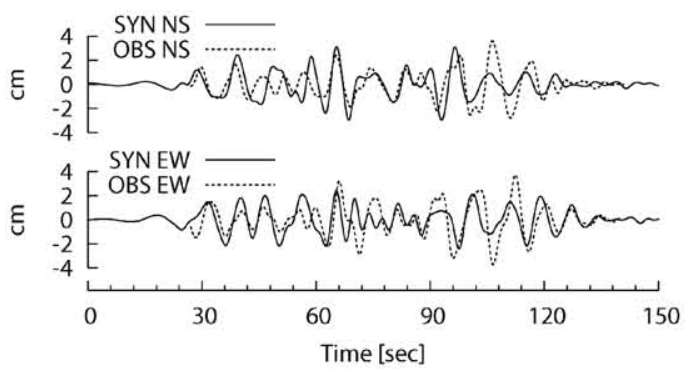

図 12 全断層による観測波の再現

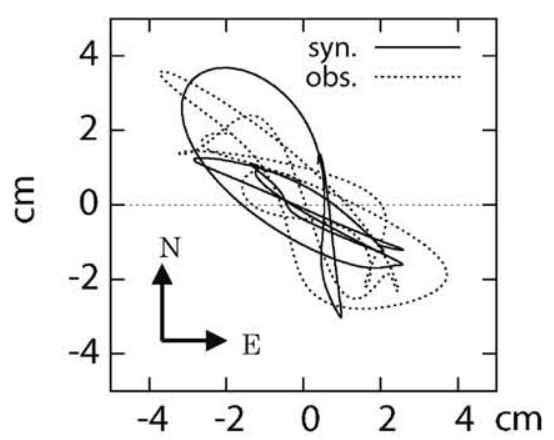

図 13 計算波の後続動の粒子軌跡 (実線は計算波, 点線は観測波) 


\section{（2）短周期の地震動の再現性による検証}

経験的グリーン関数法で図 14 に示寸 K-NET 観測点と大手町（中 央気象台), 横浜, 三島の気象官署の丹沢地震の地震動を推定し, 震 度の再現性を確認した. まず, K-NET 観測点の地震動を求めた. 地盤の非線形性を考慮するために，線形解析で地表の小地震記録を 直下の工学的基盤まで引き戻し, 地震動を推定した後, 等価線形化 法で地表に戻した. 気象官署の地震動は, K-NET 観測点と気象官署 の地盤構造の違いによる増幅特性の差異を考慮するために, 工学的 基盤まで引き戻した最寄りの K-NET 観測点の地震動を, 気象官署の 地下構造を用いて，等価線形化法により地表に戻して求めた。この ようにして得られた地震動から計測震度を算出し, 勝又による震度 分布 ${ }^{20)}$ と宇津による震度と比較した. 図 14 に震度を評価した K-NET 観測点と大手町，横浜，三島の気象官署の位置を示寸。

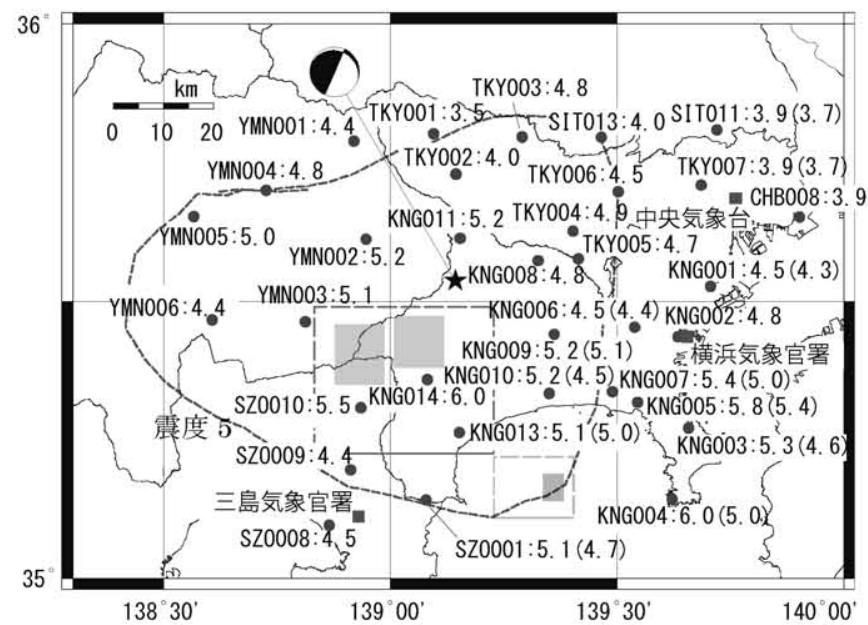

（）内はアスペリティ 1 とその背景領域からの地震波の震度

図 14 中央気象台，横浜，三島の気象官署 (一)，K-NET 観測点

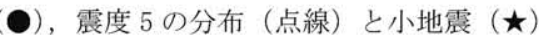

経験的グリーン関数法では，メカニズムが丹沢地震と同様で，か つアスペリティ 1 付近で発生した 2001 年 12 月 8 日の神奈川県西部 の地震 (M4.6) を小地震に用いた. 震央は気象庁による位置を用い, 媣さはF-netによる推定值（38km）を用いた。同地震の地震モーメ ントとコーナー振動数は Tsuda $\left.{ }^{5}\right)$ による推定值 $\mathrm{M}_{0}=8.64 \mathrm{e}+15 \mathrm{Nm}$, $\mathrm{fc}=1.2 \mathrm{~Hz}$ を用いた. 図 14 に小地震の震央とメカニズムを示す.

K-NET 観測点では, K-NET によるPS 検層の速度構造を用いて, 鉛直入射を仮定した重複反射理論から $\mathrm{S}$ 波速度が $400 \mathrm{~m} / \mathrm{s}$ 以上の工 学的基盤上面の地震動を算定した（以後，重複反射理論により鉛直 入射を仮定して工学的基盤上面の地震動を算定することをはぎ取り と記す)。 CHB008，KNG001，KNG009，KNG013，SIT011では PS 検層が工学的基盤に到達していないため, はぎとりに用いる工学 的基盤までの速度構造を作成する必要があった，そのため，まずこ れらの地点の工学的基盤の深さを, $300 \mathrm{~m}$ 程度以内の近傍のボーリ ング調查から推定した，次に 推定深さとなるようにPS 検層の最下 層の層厚を増大し, 密度 $1.9 \mathrm{~g} / \mathrm{cm}^{3}, \mathrm{~S}$ 波速度 $500 \mathrm{~m} / \mathrm{s}, \mathrm{P}$ 波速度 $2000 \mathrm{~m} / \mathrm{s}$ の最下層を追加して, これらの地点の速度構造を作成した．工学的 基盤深さは CHB008 で 32m，KNG001 で 25m，KNG009 で 25m, KNG013で 19m，SIT011で 40m とした。
気象官署の地震動を推定するにあっては，大手町に対しては TKY007 新宿, 横浜は KNG002 横浜, 三島は SZO008 沼津の工学 的基盤の推定波を地表に戻した. 気象官署の速度構造ははぎ取った K-NET 地点の速度構造から作成した. 大手町と横浜の気象官署の近 傍のボーリングデータを見ると, 工学的基盤の深さはそれぞれ 19m, $43 \mathrm{~m}$ であった. そこで, はぎ取った K-NET の PS 検層の速度構造を 工学的基盤深さが一致するように, 工学的基盤直上の層の層厚を修 正して大手町と横浜の気象官署の表層地盤を作成した。三島では SZO008 沼津の速度構造をそのまま用いた. 地盤のせん断剛性低減 率と減衰定数のひずみ依存性には砂地盤, 粘性土地盤の平均的な特 性 ${ }^{21)}$ 用いた。最大ひずみは横浜で最も大きく $0.25 \%$ であった.

図 14 に勝又による震度 5 の震度分布と推定波の震度を示す.震度 は水平 2 成分から計算した. 同図で（）内の数值はアスペリティ 2 とその背景領域の影響を検討するために, アスペリティ 1 とその背 景領域からの地震波のみで計算した震度である。ただし震度が同一 の場合は示していない, 震度 5 の震度分布と推定波の震度はほぼ対 応している. アスペリティ 2 の影響は震源に近い神奈川県内のみで あった. 文献 20 の表 435-1 では, 高座郡, 中郡, 愛甲郡, 鎌倉部で 被害が大きい. KNG005 鎌倉は鎌倉部，KNG010 平塚は中郡と高座 部の最寄りの観測点である. アスペリティ 2 とその背景領域を考慮 することで, これらの地点で震度が大きく増大し, 他の地域に比べ 地震被害が大きい傾向をより説明可能である.

気象官署の推定震度と宇津の震度との比較を表 3 に示す. 震度を ほぼ再現できる断層モデルであることが確認できる．図 15 に $2 \mathrm{~Hz}$ でハイカットした中央気象台の加速度の推定波を示寸。推定波は減 衰が緩やかな経時特性であり, 図 1 の HNG の記録と整合している.

表 3 観測された気象庁の測候所における震度との比較

\begin{tabular}{|c|c|c|c|}
\hline 測候所 & 宇津 & $\begin{array}{c}\text { 計測 } \\
\text { 震度 }\end{array}$ & $\begin{array}{c}\text { 計測震度 (アスペリティ1 } \\
\text { とその背景領域のみ) }\end{array}$ \\
\hline 大手町 & 4 & 4.0 & 3.9 \\
\hline 横浜 & 4 & 4.5 & 4.5 \\
\hline 三島 & 4 & 4.5 & 4.5 \\
\hline
\end{tabular}
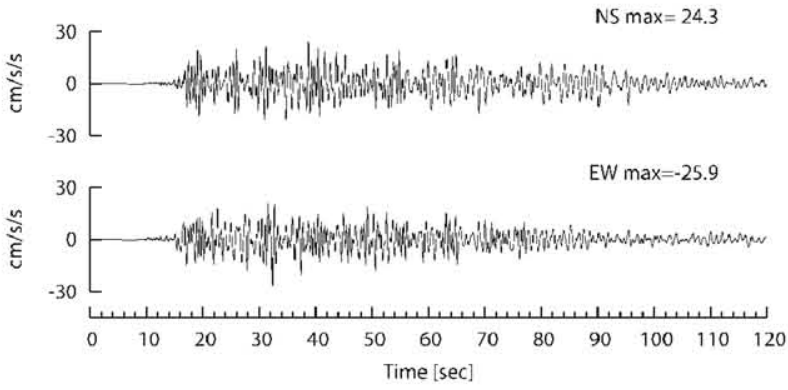

図 15 中央気象台（大手町）における加速度の推定波

\section{6. 首都圏の工学的基盤における広帯域な強震動の推定}

\section{(1) 推定概要}

短周期成分を経験的グリーン関数法で，長周期成分を三次元差分 法で算定し接続周期 3 秒でハイブリッドして広帯域な地震動を推定 した. 評価地点は図 14 に示す首都圈の K-NET 地点で, 解放工学的 
基盤面の地震動を推定した. 経験的グリーン関数法では 5(2)節で推 定した工学的基盤の地震動を水平動として用いた.

小地震の記録をみると上下動と水平動の主要動の発生時間はほぼ 一致しており, 地表の上下動は主として表層で $\mathrm{S}$ 波から変換された $\mathrm{P}$ 波と考えられた。 そこで上下動も $\mathrm{S}$ 波として波形を合成して推定 した. 上下動の解放工学的基盤へのはぎ取りは K-NET の PS 検層に よる $\mathrm{P}$ 波速度構造を用いた。

\section{（2）最大加速度, 最大速度}

図 16 に工学的基盤上面の最大加速度および最大速度を,距離減衰 式 ${ }^{22)}$ と比較して示す. 最大加速度と最大速度は水平 2 成分のうち大 きい方をプロットした，距離減衰式には等価震源距離を用いた，全 断層面を一辺 $2 \mathrm{~km}$ の要素断層に分割し, 要素断層中心と評価地点の 距離をすべり量で重み付けして平均した距離を等価震源距離とした。 最大加速度の距離减衰式は 1.4 で除して岩盤上の最大加速度として 地盤条件を合わせた，等価震源距離が $50 \mathrm{~km}$ 以内では，大きくばら つくものの平均的にみて推定波と距離減衰式は同程度である.
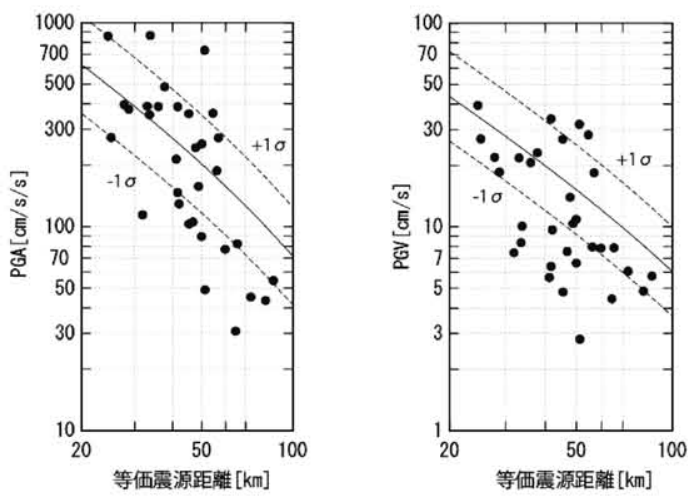

図 16 最大加速度および最大速度の距離減衰式との比較

\section{（3）速度応答スペクトル}

震源直上の KNG014 山北, 関東平野西部の KNG009 厚木, 都市中 心部の KNG002 横浜, KNG001 川崎, TKY007 新宿, CHB008 浦安 の推定波の波形と速度応答スペクトルを図 17 から図 22 にそれぞれ 示す.これらの図においては工学的基盤における速度応答スペクト ルの距離減衰式 ${ }^{23)}$ と, 建築基準法で告示された損傷限界と安全限界 のスペクトルも示した. 断層近傍の KNG014, KNG009 では周期 0.5 秒以下で距離減衰式と損傷限界のスペクトルを上回る. 距離減衰式 を上回った原因には, 震源距離, アスペリティ 1 の地震動放射特性, 地点近傍の地下構造が考えられる。応答スペクトルは距離に従い減 衰し, 周期 1 秒以下では KNG002 で損傷限界のスペクトルをやや下 回り，それより遠方の KNG001, TKY007,CHB008 では安全限界のス ペクトルをやや下回る.

堆積層が厚い KNG002, KNG001, TKY007 と CHB008 では堆積層 表面波からなる長周期地震動が眯念される. TKY007, CHB008 では 堆積層表面波による卓越が周期 5 10 秒で認められる. 同周期域の 安全限界のスペクトルと比較して KNG002, KNG001 で同レベル, 他の地点では下回った.

\section{(4) 本震との比較}

震源近傍の震度を本震の震度 ${ }^{24)}$ と比較して表 4 に示寸. 丹沢地震 の震度は等価線形化法で工学的基盤から立ち上げた地表の震度であ る. KNG009 厚木では丹沢地震の方が震度 1 程度小さいが，アスペ リティのほぼ直上の KNG014 山北では同じである. 本震の応力降下 量は KNG014 近傍のアスペリティで $12.7 \mathrm{MPa}^{25)}$ と, 丹沢地震の主要 アスペリティとほぼ同じである. KNG014 では同程度の応力降下量 のアスペリティから同程度の距離に位置したことが, 両地震で震度 が同じになった主な原因と考えられる. 横浜における周期 3.3 秒以 上の長周期地震動の速度応答スペクトル (減衰 $1 \%$ ) の本震 ${ }^{4}$ との比 較を図 23 に示す.振幅レベルは $1 / 5$ 程度と本震を大きく下回った.

\section{7. まとめ}

推定に必要なデータが十分でないものの, 都心の波形記録や震度 がほぼ再現できる不均質な丹沢地震の震源断層を推定した. 実際に 発生した首都圈のM7 規模の地震による, 都心で観測された波形を再 現した強震動評価はこれまでなかった。都心の観測波形の再現によ り首都圈の M7 規模の地震の特性を反映したことが, 本研究の最も重 要な意義である.

震源断層は二つのセグメントからなる多重震源と推定された. 神 奈川県西部に主要なアスペリティを含むセグメントが推定された. また相模湾に地震モーメントで $16 \%$ 程度の小さなアスペリティを 含むセグメントが推定された.

推定された地震動を建築基準法の告示で示されたスペクトルと比 較した。周期 0.5 秒以下は, KNG014 山北, KNG009 厚木, KNG002 横浜において損傷限界のスペクトルと同程度がそれ以上の地震動と なった. 堆積層表面波が卓越する周期 5 秒以上は, KNG002 横浜, KNG001 川崎で安全限界のスペクトルと同程度, TKY007 新宿, CHB008 浦安では下回った. 本震との比較では, 丹沢地震の主要ア スペリティの直上の KNG014 山北では本震とほぼ同じ震度であった. また長周期地震動は KNG002 横浜で本震の $1 / 5$ 程度であった。
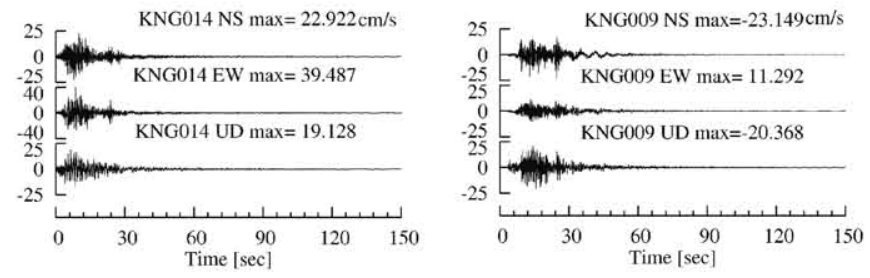

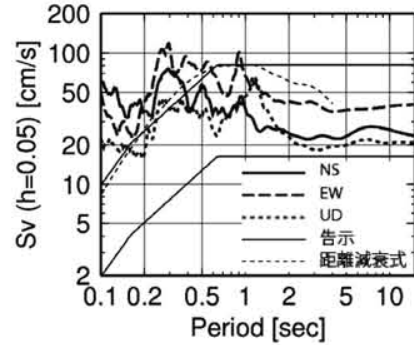

図 17 KNG014 山北の推定波 と速度応答スペクトル

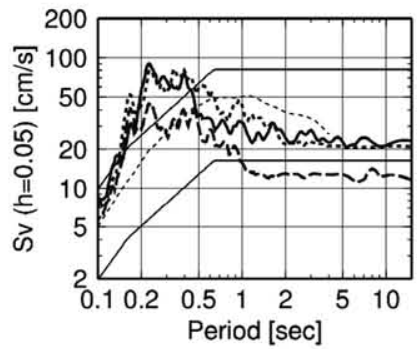

図 18 KNG009 厚木の推定波 と速度応答スペクトル 

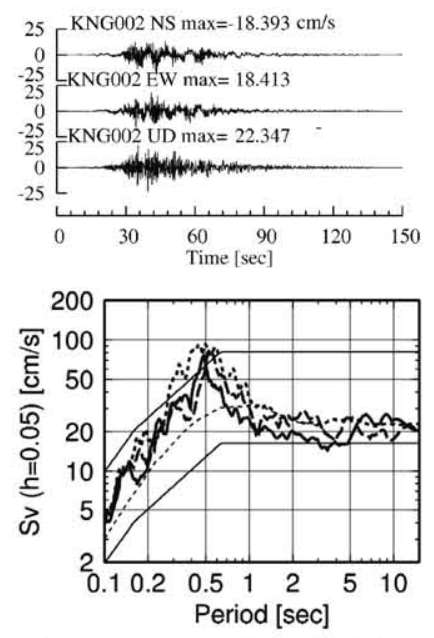

図 19 KNG002 横浜の推定波 と速度応答スペクトル
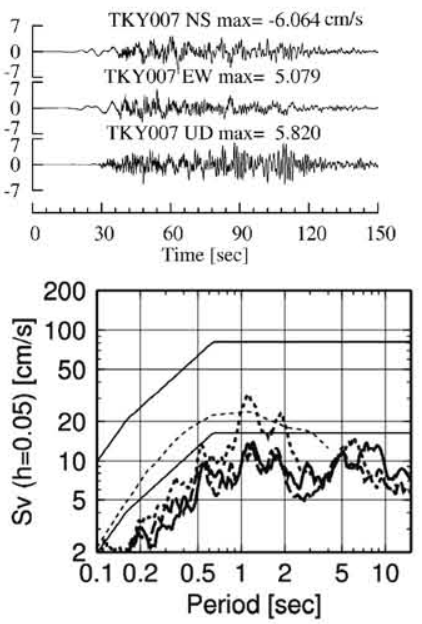

図 21 TKY007 新宿の推定波 と速度応答スペクトル

表 4 本震の震度との比較

\begin{tabular}{|c|c|c|}
\hline & $\begin{array}{c}\text { KNG014 } \\
\text { 山北 }\end{array}$ & $\begin{array}{c}\text { KNG009 } \\
\text { 厚木 }\end{array}$ \\
\hline $\begin{array}{r}\text { 丹沢 } \\
\text { 地震 }\end{array}$ & 6.0 & 5.2 \\
\hline 本震 & 6 強 & 6 強 \\
\hline
\end{tabular}

\section{謝辞}

防災科学技術研究所のK-NETの観測記録を使用させていただきま した. Ewing式地震計の記録は早稲田大学の山田眞教授から借り受 けました. 本研究の遂行には科学研究費補助金 (課題番号 18510154) の補助を受けました。ここに記して感謝いたします。

\section{参考文献}

1) 地震調查推進本部 : 海溝型地震の長期評価

(http://www.jishin.go.jp/main/p hyoka02 kaiko.htm), 2010.01.29

2) 田中康久, 三宅弘恵, 䋶縝一起, 古村孝志, 早川俊彦, 馬場俊孝, 鈴木晴彦,
増田徽: 首都圈下の速度構造の大大特統合モデル(2) : 海溝型地震のための モデル拡張とチューニング，日本地球惑星科学連合 2006 年大会予稿集, S116-P014, 2006

3) 山中浩明, 山田伸之: 微動アレイ観測による関東平野の 3 次元 $\mathrm{S}$ 波速度構 造モデルの構築, 物理探査, Vol.55, No.1, pp.53-65, 2002

4) Sato, T. Graves, R.W. and Somerville, P.G.: Three Dimensional Finite- Difference Simulations of long-Period Strong Motions in the Tokyo Metropolitan Area during the 1990 Odawara Earthquake(Mj5.1) and the Greate 1923 Kanto Earthquake(Ms8.2) in Japan, Bull. Seism. Soc. Am., Vol.89, No.3, pp.579-607, 1999

5) Kenichi Tsuda : A New Method of Site Response Estimation and Its Application to Ground Motion Prediction, PhD. thesis of Univ. of CALIFORNIA Santa Barbara, 2007

6) 三宅弘恵, 䋶類一起, 古村孝志, 稲垣賢亮, 増田徽, 翠川三郎 : 首都圈の強 震動予測のための浅層地盤構造モデルの構築, 第 12 回日本地震工学シン ボジウム論文集, pp.214-217, 2006

7) 佐藤俊明, 片岡俊一: 1924 年 1 月 15 日丹沢地震（M7.3）の震源パラメー 夕の推定, 地震学会講演予稿集,B14, pp.972-1127, 1997

8) 片岡俊一, 宮腰淳一, 佐藤俊明, 早川崇 : 1923 年関東地震の大規模余震に 上る長周期強震動, 日本地震工学会 · 大会, 2004 梗概, 354-355, 2004

9) 那須信治 : 烈強震の地動(2), 建築技術, No.237, pp. 123-134, 1971

10) 那須信治, 森岡敬樹: 烈强震の地動(4), 建築技術, No.259, pp.159-164, 1973

11) Pitarka, A. : 3D Elastic Finite-Difference Modeling of Seismic Motion Using Staggered Grids with Nonuniform Spacing, Bull. Seism. Soc. Am., 89, pp.54-68, 1999

12）国土地理院：地震予知連絡会会報, Vol.31, 1984.2

13) 地震調查推進本部 : 震源断層を特定した地震の強震動予測手法 (「レシ ピ」) (http://www.jishin.go.jp/main/p_hyoka03.htm) , 2010.1.29

14）気象庁：地震・火山月報（カタログ編）2007年 7 月 CDROM, 2007

15) Wald, D. J., and P. G. Somerville: Variable-slip rupture model of the great 1923 Kanto, Japan earthquake: geodetic and body-wave inversion analysis, Bull. Seismo. Soc. Am., 85, pp.159-177, 1995

16) 八木勇治, 伊藤喜宏, 浅野陽一, 関根秀太郎 : 2003 年 7 月 26 日宮城県北 部で発生した地震の前震・本震・最大余震の震源過程とそれぞれの関係に ついて, 地震学会講演予稿集, A086, 2003

17) 宇津德治: 日本付近の M6.0 以上の地震および被害地震の表 : 1885 年-1980 年, 震研彙報, $57, \mathrm{pp} .401-463,1982$

18) Somerville, P.G., K. Irikura, R. Graves, S. Sawada, D. Wald, N. Abrahamson, Y. Iwasaki, T. Kagawa, N.Smith, and A. Kowada: Characterizing crustal earthquake slip models for the prediction of strong ground motion, Seismological Research Letters, 70, pp.59-80, 1999

19) 中村洋光, 宮武隆: 断層近傍強震動シミュレーションのための滑り速度時 間関数の近似式, 地震第 2 輯, 第 53 巻, 第 1 号, pp.1-9, 2000

20) 宇佐美龍夫:新編日本被害地震総覧,東京大学出版会, 1987

21）国土交通省建築研究所 : 改正建築基淮法の構造関係規定の技術的背景, 2001

22）司宏俊・翠川三郎：断層タイプ及び地盤条件を考慮した最大加速度・最 大速度の距離減衰式, 日本建築学会構造系論文集, 第 523 号, pp.63-70, 1999.9

23) 安中正, 山崎文雄, 片平冬樹 : 気象庁 87 型強震記録を用いた最大地動及 び応答スペクトル推定式の提案, 第 24 回地震工学研究発表会講演論文集, pp.161-164, 1997

24) 武村雅之 : 関東大震災 大東京圈の摇れを知る, 鹿島出版会, 2003

25) 壇一男, 佐藤俊明 : 断層の非一様すべり破壊を考慮した半経験的波形合 成法による強震動予測, 日本建築学会構造系論文集, 第 509 号, pp.49-60, 1998.7

(2009年 7 月 9 日原稿受理，2010年 1 月 7 日採用決定) 